\title{
SISTEM INFORMASI PENETAPAN ANGKA KREDIT GURU BERBASIS WEB DI DINAS PENDIDIKAN KABUPATEN PELALAWAN
}

\author{
Medyantiwi Rahmawita Munzir ${ }^{1}$, Fithratul Husna², \\ Program Studi Sistem Informasi, Fakultas Sains dan Teknologi \\ Universitas Islam Negeri Sultan Syarif Kasim Riau, Pekanbaru \\ E-mail :, diantiwi0@gmail.com ${ }^{1}$, fitrahusna27@gmail.com ${ }^{2}$
}

\begin{abstract}
Abstrak
Komputer saat ini tidak asing lagi bagi setiap kalangan, khususnya didunia pendidikan dengan berbagai macam kegunaan termasuk bagi tenaga pendidik atau guru, terutama tenaga pendidik yang ingin naik pangkat melalui Angka Kredit. Dinas Pendidikan Kabupaten Pelalawan merupakan salah satu instansi pemerintahan yang bertanggung jawab terhadap semua hal yang berkaitan dengan dunia pendidikan. Dinas Pendidikan juga yang bertugas dalam menangani kenaikan jabatan fungsional dan penetapan Angka Kredit Guru (AKG). Proses penetapan AKG masih menggunakan Ms. Excel. Data yang disimpan adalah didalam Ms. Excel setiap periode kenaikan pangkat, sehingga tempat backup data ada dibanyak aplikasi. Banyaknya laporan AKG dalam satu periode sekitar 500 dokumen sementara dalam 1 tahun ada 2 periode. Hal tersebut mengakibatkan dalam proses pencarian data yang dibutuhkan akan memakan waktu yang lama. Kemudian, jumlah Tim Penilai yang hanya 5 orang memicu keterlambatan penilaian AKG. Dan guru yang jauh dari Dinas bolak-balik untuk proses kenaikan pangkat ini yang memakan waktu kurang lebih 2 hari serta biaya sekitar 500 ribu rupiah. Metode pengembangan sistem menggunakan metode Waterfall, alat bantu yang digunakan dalam menganalisa dan membangun sistem yaitu dengan metode Object Oriented Analysis Design serta pengujian sistem menggunakan Blackbox Testing dan User Acceptance Test dengan tingkat penerimaan sistem sebesar 85,04\% . Hasil dari penelitian ini adalah menghasilkan sebuah Sistem Informasi Penetapan Angka Kredit Guru Berbasis Web yang dapat membantu guru dan Instansi dalam kenaikan pangkat guru.
\end{abstract}

Kata Kunci: Angka Kredit Guru, Blackbox Testing, User Acceptence Test, Waterfall

\section{Latar Belakang}

\section{PENDAHULUAN}

Perkembangan teknologi dan informasi begitu pesat, sehingga kebutuhan akan informasi sangat diperlukan. Salah satu teknologi yang berkembang dapat dilihat dari kemunculan berbagai penggunaan aplikasi dan sistem informasi yang dapat mempermudah dan membantu user dibidang pekerjaan dengan menggunakan berbagai macam teknik pembuatan perangkat lunak. Teknologi informasi menyebabkan peran komputer begitu diperlukan dalam berbagai aspek kehidupan [1]. Penggunaan perangkat komputer juga mampu memegang peranan penting sebagai alat bantu dalam memecahkan masalah yang kecil sampai yang sangat kompleks. Komputer saat ini tidak asing lagi bagi setiap kalangan, khususnya didunia pendidikan dengan berbagai macam kegunaan termasuk bagi tenaga pendidik atau guru, terutama tenaga pendidik yang ingin meningkatkan keterampilan guna menunjang Sumber Daya Manusia yang dimiliki dan juga untuk tenaga pendidik yang ingin naik pangkat pegawai fungsional yang kenaikan pangkatnya melalui
Angka Kredit. Peningkatan mutu guru perlu dilakukan agar guru lebih mampu bekerja sebagai tenaga pendidik professional dalam melakukan tugas dan tanggung jawabnya [2].

Keputusan Bersama Menteri Pendidikan Nasional dan Kepala Badan Kepegawaian Negara Nomor: 03/V/PB/2010 dan Nomor: 14 Tahun 2010 tentang Petunjuk Pelaksanaan Jabatan Fungsional Guru dan Angka Kreditnya, Angka Kredit merupakan nilai dari tiap butir kegiatan dan/atau akumulasi nilai butir-butir kegiatan yang harus dicapai oleh seorang guru dalam rangka pembinaan karir kepangkatan dan jabatannya. Didalam keputusan tersebut berisi aturan-aturan mengenai Jabatan Fungsional dan Angka Kredit Guru yang selama ini telah berlaku secara umum.

Dinas Pendidikan Kabupaten Pelalawan merupakan salah satu instansi pemerintahan yang bertanggung jawab terhadap semua hal yang berkaitan dengan dunia pendidikan. Dinas Pendidikan juga yang bertugas dalam menangani kenaikan jabatan fungsional dan penetapan angka kredit guru. Dalam penerapan Teknologi Informasi (IT) Dinas Pendidikan membutuhkan Sistem 
Informasi, salah satunya yaitu Sistem untuk Angka Kredit Guru.

Proses penetapan angka kredit guru pada Dinas Pendidikan Kabupaten Pelalawan ditangani oleh bagian Umum dan Kepegawaian khususnya dibidang kenaikan pangkat. Proses ini masih menggunakan semi komputerisasi. Dalam proses dan pengelolaan data angka kredit guru di bagian kenaikan pangkat masih menggunakan Microsoft Excel. Setiap satu kali periode kenaikan pangkat guru, Microsoft Excel yang dipakai berbeda dengan Microsoft Excel sebelum dan sesudahnya sehingga tempat backup data ada di banyak aplikasi. Hal ini dikhawatirkan terjadinya kehilangan data. Kemudian, laporan penilaian angka kredit guru berbentuk dokumen yang terdiri dari 500 dokumen dalam satu kali periode sementara dalam setahun ada dua periode kenaikan pangkat. Hal tersebut mengakibatkan proses pencarian data yang dibutuhkan akan memakan waktu yang lama, dikarenakan harus mencari satu per satu data yang dibutuhkan.

Masalah selanjutnya, yaitu sering kali tertundanya pengajuan kenaikan pangkat guru, bukan karena guru yang tidak produktif akan tetapi dikarenakan Tim Penilai yang akan menilai Daftar Usul Penetapan Angka Kredit (DUPAK) hanya sebanyak 5 orang, sedangkan berkas yang akan dinilai jumlahnya lebih dari 200 berkas sehingga memicu terjadinya keterlambatan dalam proses penilaian Angka Kredit Guru. Unsur kegiatan yang akan dinilai dalam angka kredit terdiri atas unsur utama dan unsur penunjang [3]. Dari kedua unsur tersebut, jumlah angka kredit kumulatif minimal yang harus dipenuhi oleh setiap Guru untuk pengangkatan dan kenaikan jabatan/pangkat. Jika memenuhi jumlah angka kredit kumulatif minimal akan menghasilkan suatu Penetapan Angka Kredit (PAK) untuk guru.

Berdasarkan wawancara yang telah dilakukan bersama Bapak Suardy, S.Sos., M.H yang bertindak sebagai pengelola bidang kenaikan pangkat pada Bagian Umum dan Kepegawaian di Dinas Pendidikan Kabupaten Pelalawan, guru datang ke Dinas Pendidikan untuk mengusulkan DUPAK dan menyiapkan serta mengantarkan bahan untuk kenaikan jabatan fungsional, kemudian bahan tersebut dinilai oleh Tim Penilai Dinas Pendidikan. Jika bahan penilaian angka kredit memenuhi jumlah angka kredit kumulatif minimal, maka diterbitkanlah PAK. Lalu, guru akan datang ke Dinas Pendidikan untuk melihat lagi apakah bahan angka kreditnya sudah terpenuhi atau belum. Sedangkan untuk guru yang belum memenuhi jumlah angka kredit kumulatif minimal, guru tersebut diharuskan melengkapi kekurangan apa saja yang perlu dipenuhi untuk kenaikan jabatan fungsional guru tersebut. Oleh karena itu, guru-guru harus berulang kali datang ke Dinas Pendidikan, hal tersebut tentu membuat guru yang berada jauh dari Dinas Pendidikan seperti didaerah Kuala Kampar merasa kesulitan serta memakan waktu kurang lebih dua hari dan biaya sekitar lima ratus ribu rupiah.

Penelitian mengenai angka kredit ini juga pernah dilakukan yang mana dari penelitian ini menghasilkan Sistem Penetapan Angka Kredit Guru Berbasis Web yang sudah terotomatisasi dan terintegrasi yang dapat mempersingkat proses entry data sehingga dapat mengatasi kendala yang ada pada sistem lama [4]. Penelitian selanjutnya yang mana pada penelitian ini tingkat kesalahan pada saat pengiputan data penilaian dapat diperkecil karena dengan interface dan perhitungan oleh sistem yang telah disesuaikan dengan data aslinya yang mudah digunakan [1].

Berdasarkan permasalahan yang terjadi dan guna menghasilkan informasi yang dapat membantu Dinas Pendidikan Kabupaten Pelalawan untuk melakukan penetapan angka kredit guru, maka dari itu diperlukan Sistem Informasi untuk mengatasi kendala dan masalah pada penilaian angka kredit guru di Dinas Pendidikan Kabupaten Pelalawan untuk meminimalisir masalah ada.

Oleh karena itu, sesuai dengan permasalahan diatas penulis mengangkat judul penelitian "Sistem Informasi Penetapan Angka Kredit Guru Berbasis Web (Studi Kasus: Dinas Pendidikan Kabupaten Pelalawan)".

\section{Rumusan Masalah}

Berdasarkan latar belakang yang telah dijelaskan maka dapat diambil rumusan masalah yaitu "Bagaimana merancang dan membangun Sistem Informasi Penetapan Angka Kredit Guru Berbasis Web".

\section{Batasan Masalah}

Dalam suatu penelitian diperlukan batasanbatasan masalah. Adapun batasan masalah dalam penulisan Tugas Akhir ini, yaitu:

a. Data penelitian diambil dari Dinas Pendidikan Kabupaten Pelalawan. 
b. User pada sistem yang akan dibangun antara lain Admin, Tim Penilai, BKD dan Guru-guru dengan hak akses yang berbeda.

c. Sistem Informasi Penetapan Angka Kredit Guru ini dibuat dalam lingkup guru SD dan SMP.

d. Sistem Informasi Penetapan Angka Kredit Guru ini dibuat berbasis web

e. Menggunakan metode analisis sistem Objectoriented Analysis and Design (OOAD) dengan pemodelan Unified Modelling Language (UML).

f. Metode pengembangan sistem menggunakan metode Waterfall yang hanya sampai pada tahap testing menggunakan Blackbox Testing dan User Acceptance Test (UAT).

g. Penelitian ini tidak sampai pada tahap keamanan dan perawatan sistem.

\section{Tujuan Penelitian}

Tujuan dari penyusunan Tugas Akhir ini adalah untuk menghasilkan sebuah sistem yang dapat membantu dalam proses penetapan Angka Kredit Guru.

\section{Manfaat Penelitian}

Adapun manfaat yang dicapai pada penelitian ini adalah sebagai berikut:

a. Dengan adanya sistem ini instansi dapat meningkatkan kinerja dan mempermudah tim penilai dalam memproses penetapan angka kredit guru pada Dinas Pendidikan Kabupaten Pelalawan.

b. Dengan adanya sistem, dapat membantu memudahkan proses kenaikan pangkat bagi guru yang tinggal jauh dari Dinas Pendidikan.

\section{LANDASAN TEORI}

\section{Sistem Informasi}

Sistem informasi adalah suatu kombinasi yang terorganisasi dari orang, perangkat keras, perangkat lunak, jaringan komunikasi, sumber data, kebijakan dan prosedur yang menyimpan, mengambil, mengubah dan menyebarluaskan informasi dalam suatu organisasi [5].

\section{Web}

World Wide Web adalah atau yang dikenal juga dengan istilah web adalah suatu sistem yang barkaitan dengan dokumen digunakan sebagai media untuk menampilkan teks, gambar, multimedia dan lainnya pada jaringan internet”.
Web memudahkan pengguna komputer untuk berinteraksi dengan pelaku internet lainnya dan menelusuri informasi di internet [6].

\section{Hypertext Preprocessor (PHP)}

Menurut Ardhana (2012:88) PHP merupakan pengembangan dari FI atau Form Interface yang dibuat oleh Rasmus Lerdoff pada tahun 1995". Berbeda dengan HTML, kode PHP tidak diberikan langsung oleh server ketika ada permintaan dari sisi client namun dengan cara pemrosesan dari sisi server. Kode PHP disisipkan pada kode HTML. Perbedaan dari kode (script) HTML dan PHP yaitu setiap kode PHP ditulis selalu diberi tag pembuka yaitu <? Dan pada akhir kode PHP diberi tag penutup yaitu ?>. PHP sangat berperan besar ketika ingin membuat website keren yang dinamis karena dapat melakukan banyak hal, seperti membaca file, menulis file, menampilkan gambar, animasi atau movie dan yang paling pokok adalah dapat melakukan koneksi terhadap database [7].

\section{Blackbox Testing}

Blackbox testing adalah pengujian perangkat lunak dari segi spesifikasi fungsional tanpa menguji desain dan kode program. Pengujian dimaksudkan untuk mengetahui fungsi-fungsi, masukan, dan keluaran dari perangkat lunak sesuai dengan spesifikasi yang dibutuhkan. Blackbox testing dengan membuat kasus uji bersifat mencoba semua fungsi dengan memakai perangkat lunak apakah sesuai dengan spesifikasi yang dibutuhkan [8].

\section{User Acceptance Test (UAT)}

Menurut Perry (2006:70), User Acceptance Testing merupakan pengujian yang dilakukan oleh end-user dimana user tersebut adalah staff/karyawan perusahaan yang langsung berinteraksi dengan sistem dan dilakukan verifikasi apakah fungsi yang ada telah berjalan sesuai dengan kebutuhan/fungsinya. User Acceptance Testing adalah metode testing dimana pengguna akhir melakukan percobaan untuk memvalidasi produk berdasarkan kebutuhan yang telah ditentukan. Pengujian ini bertujuan untuk membantu menemukan bug yang akan muncul pada saat penggunaan [9].

\section{Konsep Dasar Jabatan Fungsional}

Berdasarkan Peraturan Menteri Negara Pendayagunaan Aparatur Negara dan Reformasi 
Birokrasi Nomor 16 tahun 2009 tentang Jabatan Fungsional Guru dan Angka Kreditnya, pengertian jabatan fungsional guru adalah jabatan fungsional yang mempunyai ruang lingkup, tugas, tanggung jawab dan wewenang untuk melakukan kegiatan mendidik, mengajar, membimbing, mengarahkan, melatih, menilai, dan mengevaluasi peserta didik pada pendidikan anak usia dini jalur pendidikan formal, pendidikan dasar, dan pendidikan menengah sesuai dengan peraturan perundangundangan yang diduduki oleh Pegawai Negeri Sipil [3].

Jenjang Jabatan Fungsional Guru dari yang terendah sampai dengan yang tertinggi adalah dijelaskan dalam gambar 2.1 dibawah ini.

Gambar 2.1 Jabatan Fungsional Guru serta Pangkat dan Golongan Ruang

\begin{tabular}{|c|c|c|c|c|}
\hline \multirow{2}{*}{\multicolumn{2}{|c|}{$\begin{array}{rr}\text { N Jabatan } \\
\text { o ungsional } \\
\text { Guru }\end{array}$}} & \multirow[t]{2}{*}{$\begin{array}{c}\text { Pangkat dan Golongan } \\
\text { ruang }\end{array}$} & \multicolumn{2}{|c|}{$\begin{array}{c}\text { Persyaratan AK } \\
\text { kenaikan } \\
\text { pangkat/jabatan }\end{array}$} \\
\hline & & & $\begin{array}{c}\text { Komulatif } \\
\text { Minimal }\end{array}$ & $\begin{array}{c}\text { Per } \\
\text { jenjan } \\
\text { g }\end{array}$ \\
\hline \multirow[t]{2}{*}{$\mathbf{1}$} & \multirow{2}{*}{$\begin{array}{l}\text { Guru } \\
\text { Pertama }\end{array}$} & Penata Muda, III a & 100 & 50 \\
\hline & & Penata Muda Tingkat I, III b & 150 & 50 \\
\hline \multirow[t]{2}{*}{2} & Guru & Penata, III c & 200 & 100 \\
\hline & Muda & Penata Tingkat I, III d & 300 & 100 \\
\hline \multirow[t]{3}{*}{3} & Guru & Pembina, IV/a & 400 & 150 \\
\hline & Madya & Pembina Tingkat I, IV b & 550 & 150 \\
\hline & & Pembina Utama Muda, IVc & 700 & 150 \\
\hline \multirow[t]{2}{*}{4} & Guru & Pembina Utama Madya, IV d & 850 & 200 \\
\hline & Utama & Pembina Utama, IVe & 1050 & - \\
\hline
\end{tabular}

\section{Konsep Dasar Angka Kredit Guru}

Berdasarkan Peraturan Bersama Mentri

Pendidikan Nasional dan Kepala Badan

Kepegawaian Negara Nomor: 03/V/PB/2010 dan Nomor: 14 tahun 2010 tentang Petunjuk Pelaksanaan Jabatan Fungsional Guru dan Angka Kreditnya, pengertian Angka Kredit adalah adalah satuan nilai dari tiap butir kegiatan dan/atau akumulasi nilai butir-butir kegiatan yang harus dicapai oleh seorang Guru dalam rangka pembinaan karier kepangkatan dan jabatannya [3].

Berdasarkan Permenpan dan RB Nomor 16 tahun 2009 tentang Jabatan Fungsional Guru dan Angka Kreditnya, sebelum para guru mengajukan kenaikan jabatan fungsional tentunya harus memenuhi beberapa kriteria terlebih dahulu, yaitu Unsur Utama dan Unsur Penunjang, yang mana adalah unsur pendidikan, unsur pembelajaran/bimbingan dan tugas tertentu, unsur pengembangan keprofesian berkelanjutan dan unsur penunjang tugas guru. Dari beberapa kriteria tersebut nantinya tiap kriteria akan diberi penilaian dengan angka tertentu dan hasil akhir yang diperoleh adalah berupa angka kredit. Angka kredit itulah yang digunakan sebagai dasar pengajuan kenaikan jabatan fungsional guru. Jumlah angka kredit kumulatif minimal yang harus dipenuhi oleh setiap Pegawai Negeri Sipil untuk pengangkatan dan kenaikan jabatan/pangkat Guru adalah paling kurang 90\% (sembilan puluh persen) angka kredit berasal dari unsur utama dan paling banyak $10 \%$ (sepuluh persen) angka kredit berasal dari unsur penunjang [3].

Berdasarkan Permenpan dan RB Nomor 16 Tahun 2009 Pasal 14, unsur kegiatan yang dinilai dalam memberikan angka kredit terdiri atas Unsur utama dan Unsur penunjang.

\section{Model Pengembangan Waterfall}

Model Waterfall SDLC adalah proses pengembangan perangkat lunak berurutan di mana kemajuan dianggap mengalir semakin ke bawah (mirip dengan air terjun) melalui daftar fase yang harus dijalankan agar berhasil membangun perangkat lunak komputer. Awalnya, model Waterfall diusulkan oleh Winston W. Royce pada tahun 1970 untuk menggambarkan praktek rekayasa perangkat lunak yang mungkin. Model Waterfall mendefinisikan beberapa fase berturutturut yang harus diselesaikan satu demi satu dan pindah ke fase berikutnya hanya ketika fase sebelumnya benar-benar selesai. Untuk alasan ini, model Waterfall bersifat rekursif karena setiap fase dapat diulang tanpa henti sampai disempurnakan [10]. Adapun model pengembangan Waterfall seperti gambar 2.2 berikut:

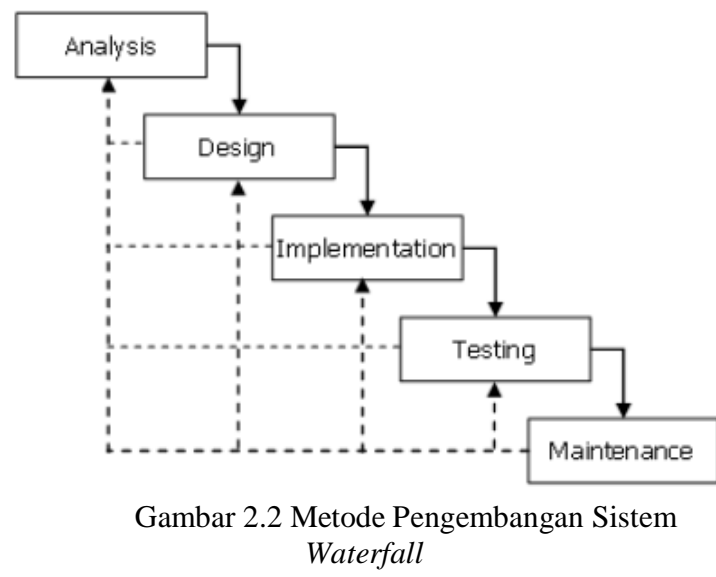

\section{METODOLOGI PENELITIAN}

Bab ini menjelaskan tentang metodologi yang dilakukan dalam penelitian dan dapat dijabarkan seperti pada gambar 3.1 berikut: 


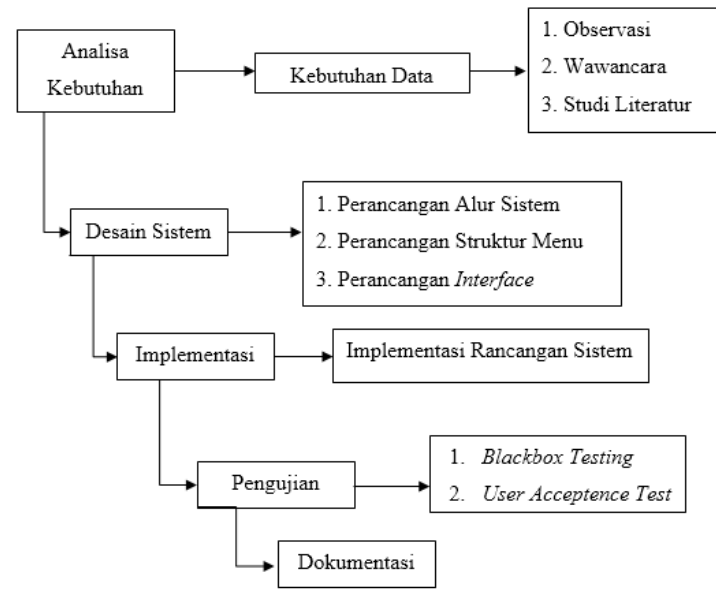

Gambar 3.1 Metodologi Penelitian

\section{ANALISA DAN PERANCANGAN}

\section{Analisa Sistem Berjalan}

Analisa sistem yang sedang berjalan merupakan langkah pertama yang harus dilaksanakan sebelum memberikan gambaran sistem yang akan diusulkan. Karena harus ada landasan untuk membangun sebuah sistem, bisa berupa permasalahan yang terjadi dan harus segera diselesaikan agar tidak menggangu proses bisnis. Berikut ini merupakan flowchart sistem yang sedang berjalan di Dinas Pendidikan Kabupaten Pelalawan. Flowchart berjalan dapat dilihat pada gambar 4.1 dibawah ini.

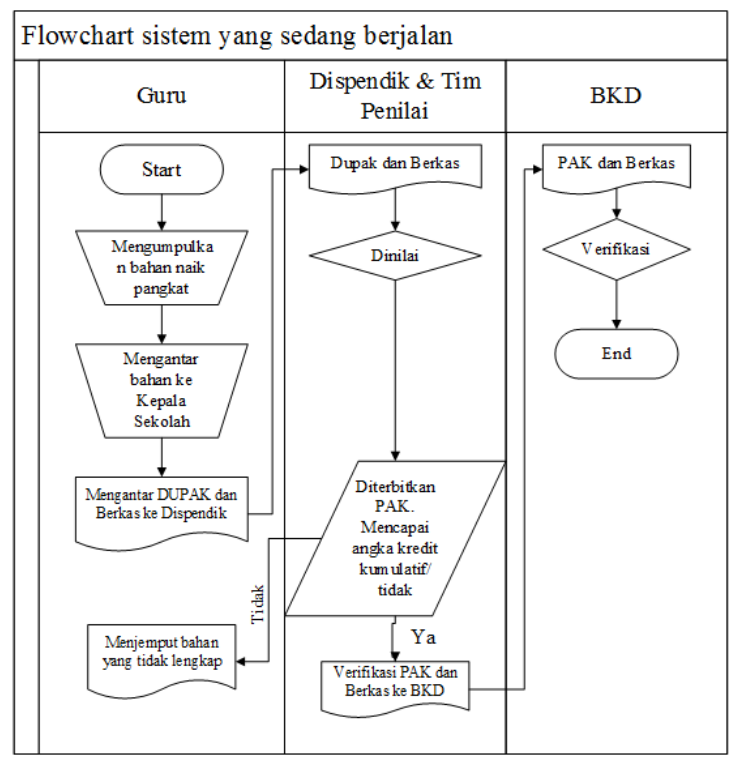

Gambar 4.1 Flowchart Sistem Berjalan

Berikut ini adalah penjelasan dari gambar 3 mengenai sistem yang berjalan saat ini di Dinas Pendidikan Kabupaten Pelalawan:

1. Guru mengumpulkan bahan-bahan kenaikan pangkat.
2. Kemudian, diantar ke Kepala Sekolah untuk membuat Daftar Usul Penetapan Angka Kredit (DUPAK) guru tersebut.

3. Guru membawa DUPAK dan bahan kenaikan pangkat tersebut ke Dinas Pendidikan untuk dinilai oleh tim penilai.

4. Tim penilai menilai, lalu diterbitkanlah Penetapan Angka Kredit (PAK).

5. Lalu, guru akan datang ke Dinas Pendidikan untuk melihat PAK yang sudah dinilai, apakah penilaian dan bahan angka kreditnya sudah terpenuhi atau belum. Jika memenuhi, maka akan diteruskan ke BKP2D untuk disampaikan kepada BKN. Jika tidak, bahan kenaikan pangkat tersebut dikembalikan kepada guru yang bersangkutan.

6. BKD memverifikasi kembali PAK yang terbit.

7. Selesai.

\section{Analisa Sistem Usulan}

Untuk memenuhi permasalahan dan kelemahan dari analisa sistem yang sedang berjalan, maka akan diusulkan perancangan Sistem Informasi Penetapan Angka Kredit Guru yang berbasis web. Sistem yang dirancang nantinya akan menjadi solusi serta mendukung proses penetapan Angka Kredit Guru Berbasis Web dan proses kenaikan jabatan guru. Perancangan sistem usulan akan memberikan gambaran dan penjelasan secara detail mengenai bentuk dan rancangan kerja dari sistem usulan dalam memenuhi kebutuhan operasional organisasi.

Sistem usulan ini dapat menampilkan berbagai informasi terkait dengan proses penetapan Angka Kredit Guru Berbasis Web. Sistem ini menggunakan database sebagai tempat penyimpanan data guru dan data kenaikan jabatan guru.

Berdasarkan hasil analisis yang telah didapatkan pada bab sebelumnya, dapat dilakukan rancangan Sistem Informasi Penetapan Angka Kredit Guru Berbasis Web pada Dinas Pendidikan Kabupaten Pelalawan menggunakan pendekatan berorientasi objek yaitu dengan menggunakan diagram Unifield Modeling Language (UML). Adapun diagram UML yang digunakan sebagai berikut:

1. Use case diagram

2. Class diagram

\section{Use Case Diagram}

Use case diagram merupakan pemodelan untuk menggambarkan kelakuan (behavior) sistem yang 
akan dibuat [11]. Berikut ini merupakan use case diagram sistem usulan dapat dilihat pada gambar 4.2 berikut.

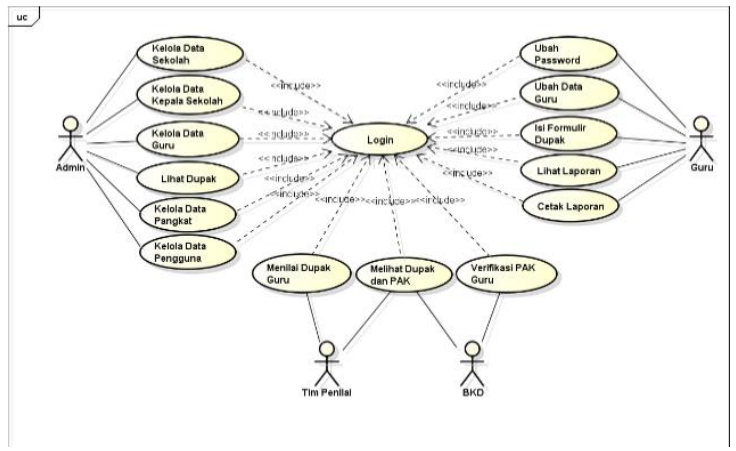

Gambar 4.2 Use Case Diagram

Adapun aktor-aktor yang terlibat didalam Sistem Informasi Penetapan Angka Kredit Guru terlihat pada Tabel 4.1 dibawah ini :

Tabel 4.1 Aktor yang terlibat di dalam sistem

\begin{tabular}{|c|c|c|}
\hline No & Actor & Description \\
\hline 1 & Admin & $\begin{array}{l}\text { Admin mempunyai hak dan } \\
\text { wewenang } \\
\text { mengakses segala akses } \\
\text { sistem yang ada pada } \\
\text { Sistem. }\end{array}$ \\
\hline 2 & $\begin{array}{l}\text { Tim } \\
\text { Penilai }\end{array}$ & $\begin{array}{l}\text { Tim Penilai mempunyai } \\
\text { hak dan wewenang untuk } \\
\text { mengakses penilaian angka } \\
\text { kredit guru pada sistem }\end{array}$ \\
\hline 3 & Guru & $\begin{array}{l}\text { Guru mempunyai hak dan } \\
\text { wewenang untuk mengisi } \\
\text { form DUPAK. Guru juga } \\
\text { dapat mengetahui nantinya, } \\
\text { apakah penilaian angka } \\
\text { kreditnya memenuhi } \\
\text { jumlah angka kredit } \\
\text { kumulatif atau tidak. }\end{array}$ \\
\hline 4 & BKD & \begin{tabular}{lrr} 
BKD (Badan & Kepegawaian \\
Daerah) & mempunyai \\
wewenang & \multicolumn{2}{r}{ untuk } \\
memverifikasi & PAK yang \\
dikeluarkan & oleh & Tim \\
Penilai. & & \\
\end{tabular} \\
\hline
\end{tabular}

\section{Class Diagram}

Class diagram adalah diagam yang digunakan untuk menampilkan beberapa kelas serta paketpaket yang ada dalam sistem/perangkat lunak yang sedang kita gunakan. Diagram kelas memberi gambaran/diagram statis tentang sistem/perangkat lunak dan relasi-relasi yang ada didalamnya. Adapun diagram class pada sistem yang diusulkan adalah seperti yang terlihat pada gambar 4.3 berikut:

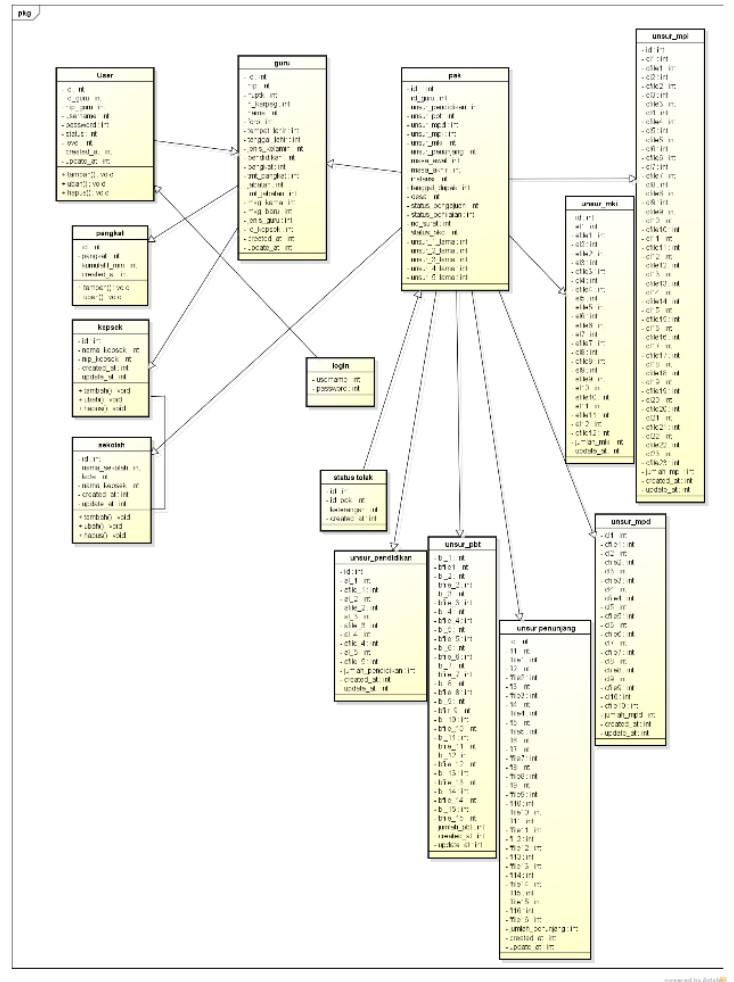

Gambar 4.3 Class Diagram

\section{Perancangan Struktur Menu}

Berikut ini merupakan perancangan struktur menu Sistem Informasi Penetapan Angka Kredit Guru Berbasis Web dapat dilihat pada gambar 4.4 dibawah ini.

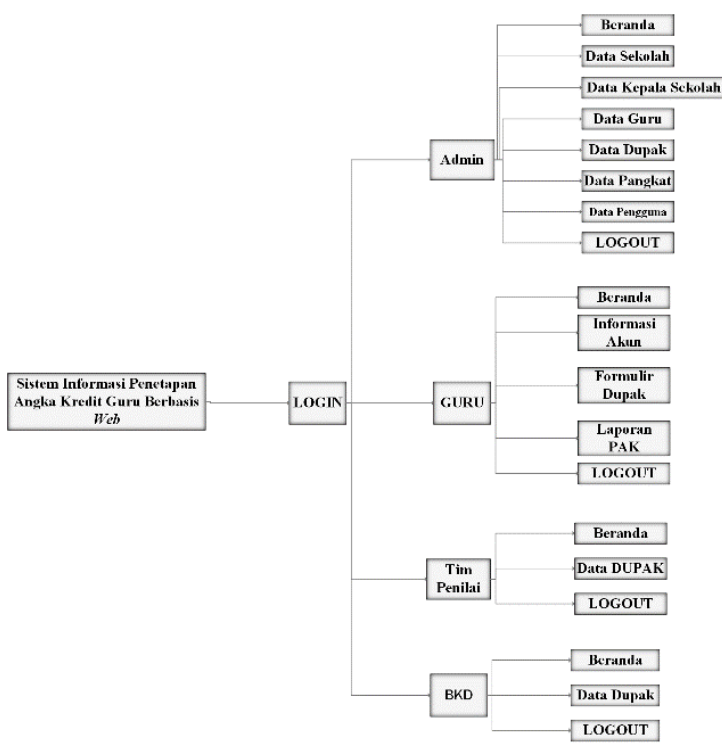

Gambar 4.4 Perancangan Struktur Menu 


\section{IMPLEMENTASI DAN PENGUJIAN}

1. Implementasi Sistem

a. Halaman Login

Berikut implementasi halaman login dapat dilihat dari gambar 5.1.

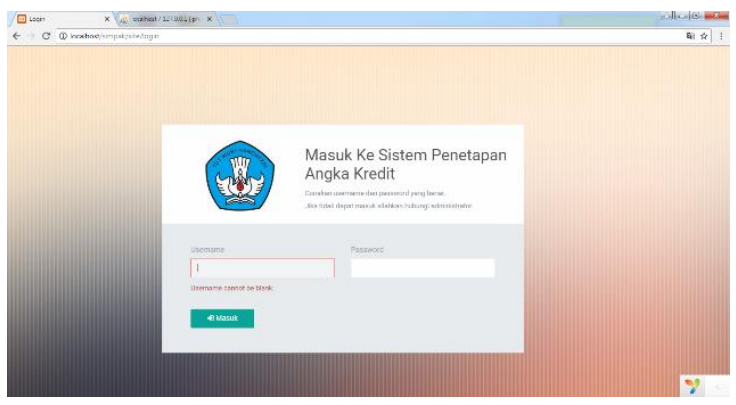

Gambar 5.1 Halaman Login

b. Halaman Utama Admin

Berikut halaman utama admin terlihat pada gambar 5.2.

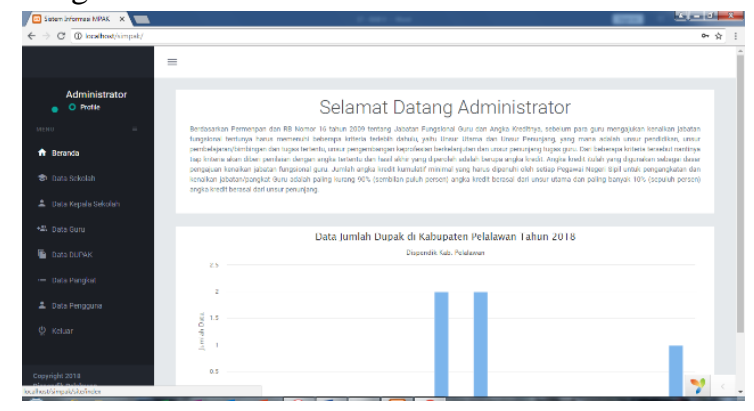

Gambar 5.2 Halaman Utama Admin

c. Halaman Input Dupak Lama

Berikut halaman input data dupak lama dapat dilihat pada gambar 5.3.

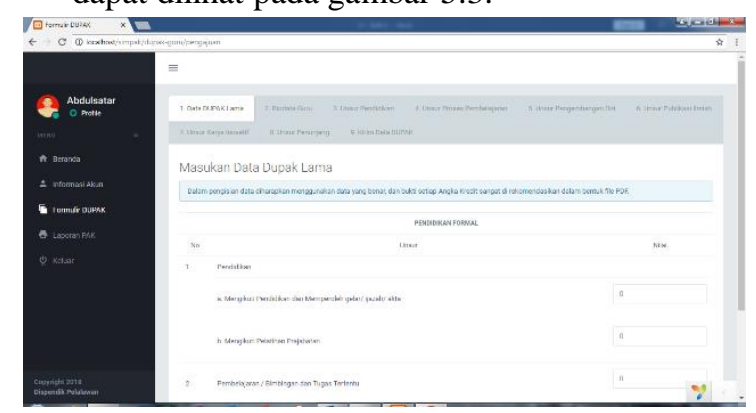

Gambar 5.3 Halaman Input Dupak Lama

d. Halaman Isi Form Dupak

Berikut halaman isi form dupak dapat dilihat pada gambar 5.4.

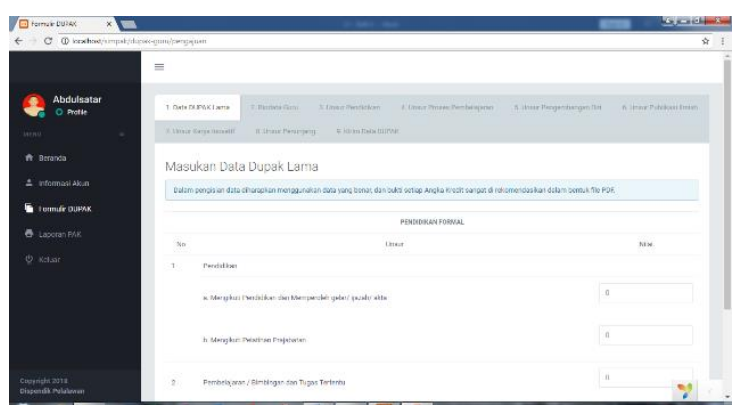

Gambar 5.4 Isi Form Dupak

e. Halaman Penilaian Dupak oleh Tim Penilai Berikut halaman penilaian dupak oleh tim penilai dapat dilihat pada gambar 5.5.

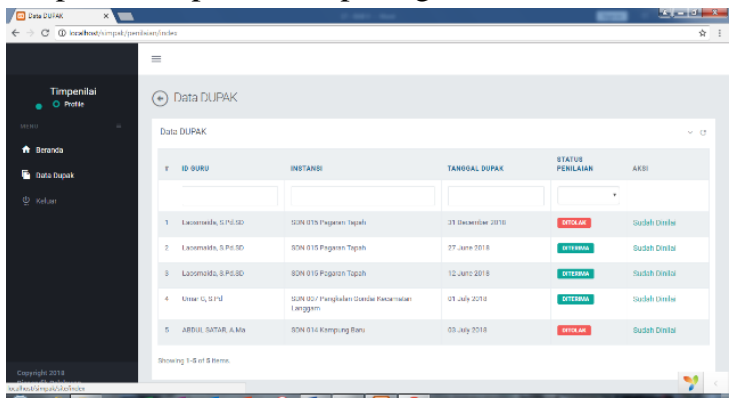

Gambar 5.5 Halaman Penilaian Dupak oleh Tim Penilai

f. Halaman Verifikasi oleh BKD

Berikut halaman verifikasi oleh BKD dapat dilihat pada gambar 5.6.

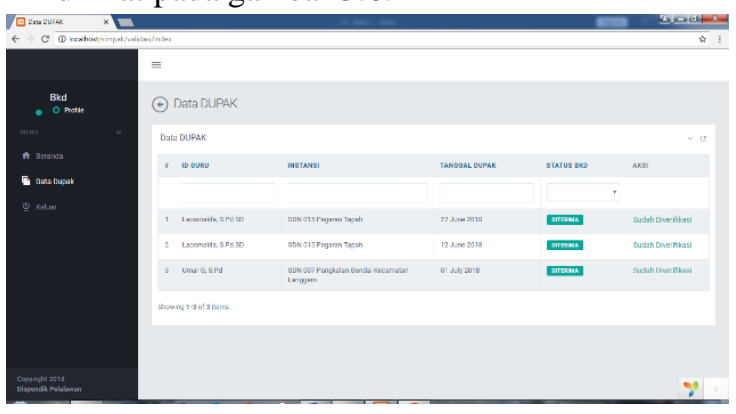

Gambar 5.6 Halaman Verifikasi oleh BKD

g. Halaman Laporan Data Dupak

Berikut halaman laporan data dupak dapat dilihat pada gambar 5.7.

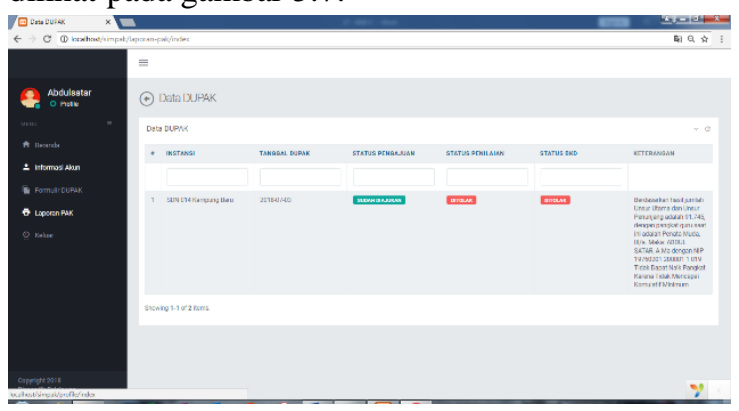

Gambar 5.7 Halaman Laporan Data Dupak 
h. Halaman Penetapan Angka Kredit Guru

Berikut halaman penetapan angka kredit guru dapat dilihat pada gambar 5.8 .

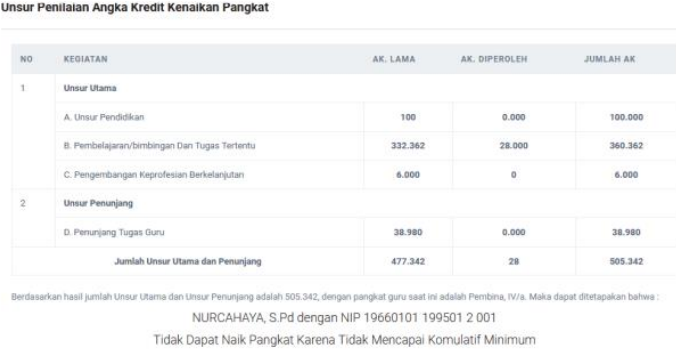

Gambar 5.8 Halaman Laporan Penetapan Angka Kredit Guru

i. Halaman Cetak Dupak Guru

Berikut halaman cetak dupak guru dapat dilihat pada gambar 5.9.

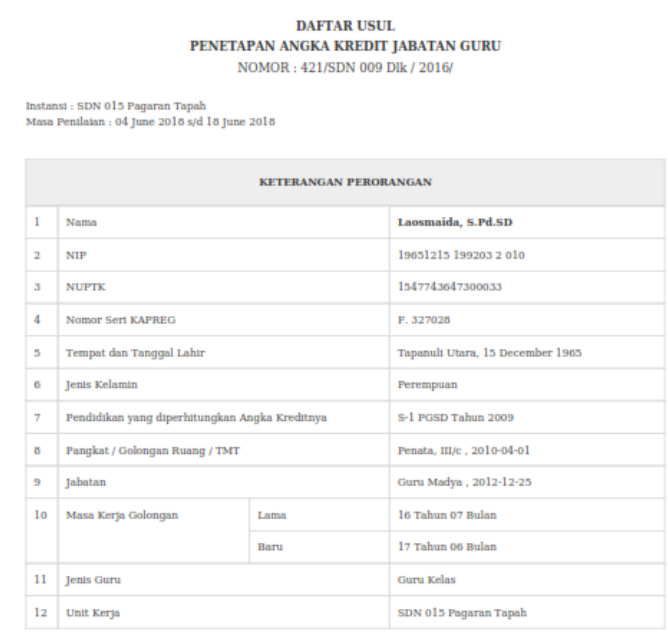

Gambar 5.9 Halaman Cetak Dupak Guru

\section{Pengujian Sistem}

Tahapan implementasi sistem merupakan kegiatan penulisan kode program yang dieksekusi oleh komputer berdasarkan algoritma tiap fitur yang yang dihasilkan pada tahapan analisa dan perancangan. Sebelum perangkat lunak (sistem) diterapkan, maka perangkat lunak tersebut harus bebas dari kesalahan-kesalahan yang mungkin terjadi yaitu dengan cara pengujian sistem. Setelah tahap implementasi selesai, maka dilanjutkan dengan pengujian dari implementasi yang telah dibangun. Pengujian sistem dilakukan dengan tujuan untuk menjamin sistem yang dibangun sesuai dengan hasil analisa dan perancangan sehingga dapat dibuat suatu kesimpulan akhir. Ada 2 pengujian yang dilakukan terhadap Sistem
Informasi Penetapan Angka Kredit Guru ini, yaitu pengujian Blackbox Testing dan User Acceptence Test.

\section{a. Blacbox Testing}

Jenis pengujian Blackbox adalah dimana proses uji ditampilkan dalam bentuk tabel yang didalamnya menjelaskan tentang deskripsi pengujian, pre-kondisi awal, prosedur pengujian, data masukkan yang digunakan, keluaran yang diharapkan, kriteria evaluasi hasil, hasil yang didapat dari pengujian dan terakhir kesimpulan pengujian. Teknik yang digunakan untuk melakukan test cases pada sistem yang dibangun ini disebut Functional Analysist.

Berikut cara memperoleh hasil dari pengujian sistem dengan menggunakan metode Blackbox pada Sistem Informasi Penetapan Angka Kredit Guru:

Presentasi Kegagalan : Jumlah Modul Error Jumlah Total

Modul

$$
\begin{aligned}
& \mathrm{X} 100 \% \\
& : \frac{0}{19} \times 100 \\
& : 0 \%
\end{aligned}
$$

Presentasi keberhasilan: 100 - 0

$$
\text { : } 100 \%
$$

Berdasarkan hasil pengujian dengan sample uji yang telah dilakukan peneliti kesimpulan bahwa sistem ini dapat digunakan dengan baik, namun pengujian tersebut dapat dikatakan belum sempurna, karena hanya dilakukan pada satu sisi pengujian. Dari semua yang telah dilakukan dalam pengujian ini diharapkan dapat mewakili pengujian fungsi yang lain.

\section{b. User Acceptance Test}

Pengujian User Acceptance Test merupakan pengujian dengan cara memberikan kuisioner yang berisi pertanyaan seputar sistem informasi penetapan angka kredit guru kepada pengguna (user). Dalam hal ini terdiri dari 17 responden yang terdiri dari 10 orang Guru, 5 orang Tim Penilai, 1 orang pihak Dinas Pendidikan dan 1 orang pihak Badan Kepegawaian Daerah Kabupaten Pelalawan. Pengujian dilakukan dengan cara pengguna (user) menggunakan sistem kemudian user mengisi form pengujian User Acceptance Test yang berisi penilaian. 
Berdasarkan hasil pengolahan data UAT terhadap 17 orang responden, user menerima adanya aplikasi dengan tingkat penerimaan sebesar 85,04\%. Responden setuju jika Sistem Informasi Penetapan Angka Kredit Guru Berbasis Web mudah digunakan (pertanyaan 1) dengan tingkat penerimaan $86,7 \%$. Responden setuju jika semua menu dari sistem ini dapat diakses (pertanyaan 2) dengan tingkat penerimaan 95,5\%. Responden setuju jika tampilan dan desain sistem sudah menarik (pertanyaan 3) dengan tingkat penerimaan $83,8 \%$. Responden setuju jika semua button dapat dipahami (pertanyaan 4) dengan tingkat penerimaan $86,7 \%$. Responden setuju jika sistem ini layak untuk diterapkan (pertanyaan 5) dengan tingkat penerimaan $77,9 \%$. Dan responden setuju jika sistem ini dapat membantu pengisian penetapan angka kredit guru (pertanyaan 6) dengan tingkat penerimaan $79,4 \%$.

\section{PENUTUP}

\section{Kesimpulan}

Berdasarkan penelitian yang dilakukan di bagian Kenaikan Pangkat di Dinas Pendidikan Kabupaten Pelalawan maka dapat diambil kesimpulan yaitu Sistem Informasi Penetapan Angka Kredit Guru berbasis Web pada Dinas Pendidikan Kabupaten Pelalawan dapat membantu staff pegawai, guru dan BKD dalam kenaikan pangkat dan mengelola data pangkat guru.

\section{Saran}

Dari kesimpulan yang telah dikemukakan diatas maka menyarankan beberapa hal sebagai berikut:

a. Pembangunan Sistem Informasi Penetapan Angka Kredit Guru ini masih bisa dikembangkan lebih lanjut terutama dalam isi dan tampilan sistemnya.

b. Penambahan fitur-fitur keamanan agar sistem tidak dapat dimasuki oleh pihak yang tidak bertanggung jawab.

c. Agar pihak instansi dapat menyempurnakan sistem ini untuk dapat melaksanakan kenaikan pangkat tepat waktu.

\section{DAFTAR PUSTAKA}

[1] Muzakir, A. "Rancang Bangun Sistem Pengolahan Data Angka Kredit Untuk Manajemen Jabatan Fungsional Dosen Di Universitas Bina Darma Palembang", 6. 2014.
[2] Fahmi, A., Rahmawati, R., \& Nuswantoro, U. D. (t.t.). "Sistem Informasi Penetapan Angka Kredit (Pak) Untuk Kenaikan Pangkat Pada Jabatan Fungsional Guru (Study Kasus Dinas Pendidikan Kota Xyz)", 11(1), 12. 2012.

[3] Menteri Negara Pendayagunaan Aparatur Negara Dan Reformasi Birokrasi. Peraturan Menteri Negara Pendayagunaan Aparatur Negara Dan Reformasi Birokrasi Nomor 16 Tahun 2009 Tentang Jabatan Fungsional Guru Dan Angka Kreditnya. CV. Pustaka Setia. 2016.

[4] Prabowo, N, A., \& Hidayah, N. "Sistem Penetapan Angka Kredit untuk Kenaikan Pangkat Guru di Lingkungan Pemerintah Kota Magelang Berbasis Web". Scientific Journal of Informatics, 2(2), 155. https://doi.org/10.15294/sji.v2i2.5084. 2016.

[5] O’Brien, J, A., \& Marakas, George, M. Introduction to Information Systems (fifteenth edition). New York: McGraw Hill Companies. Inc. 2010.

[6] Sagita, R, A., \& Sugiarto, H. "Penerapan Metode Waterfall Pada Sistem Informasi Penjualan Furniture Berbasis Web", 5(4), 7. 2016.

[7] Tabrani, M., \& Pudjiarti, E. "Penerapan Metode Waterfall Pada Sistem Informasi Inventori Pt. Pangan Sehat Sejahtera", 1(2), 11. 2017.

[8] Graham, D., Van Veenendaal, E., \& Evans, I. Foundations of software testing: ISTQB certification. Cengage Learning EMEA. 2008.

[9] Wong, K., Sinsuw, A, A, E., Mt, S., \& Najoan, X, B, N. "Rancang Bangun Aplikasi "Trip Alone?" Berbasis Android", 9(1), 7. 2016.

[10] Bassil, Y, A "Simulation Model for the Waterfall Software Development Life Cycle". International Journal of Engineering, 2(5), 7. 2012.

[11] Sugiarti, Y. Analisis dan Perancangan UML (Unified Modelling Language) Generated VB. 6 - Disertai Contoh Studi Kasus dan Interface Web - Edisi Pertama (Pertama). Yogyakarta: Graha Ilmu. 2013. 